Nevada

DOE/NV--512-Rev. 1

Environmental

Restoration

Project

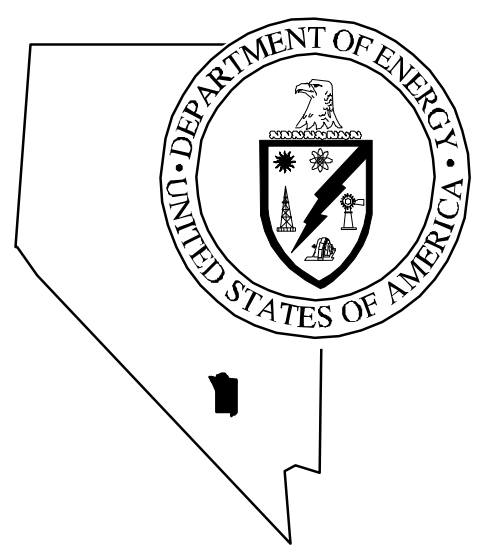

Corrective Action Decision Docum ent/

Closure Report for

Corrective Action Unit 485 :

Cactus Spring Ranch Pu and DU Site,

Tonopah Test Range, Nevada

Controlled Copy N 0.: Uncontrolled

Revision N 0.: 1

September 1998

Approved for public release; further dissemination unlimited.

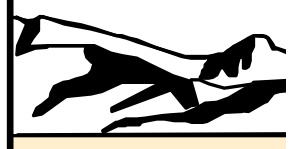

Environm ental Restoration

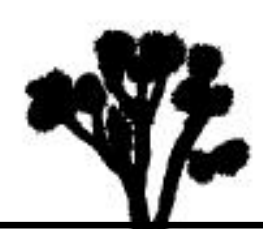

Division 
Available to the public from -

U.S. Department of Commerce

National Technical Information Service

5285 Port Royal Road

Springfield, VA 22161

(703) 487-4650

Available electronically at http://www.doe.gov/bridge. Available to U.S. Department of Energy and its contractors in paper from -

U.S. Department of Energy

Office of Scientific and Technical Information

P.O. Box 62

Oak Ridge, TN 37831-0062

(423) 576-8401 


\title{
CORRECTIVE ACTION DECISION DOCUMENT/ CLOSURE REPORT FOR CORRECTIVE ACTION UNIT 485: CACTUS SPRING RANCH PU AND DU SITE, TONOPAH TEST RANGE, NEVADA
}

\author{
DOE Nevada Operations Office \\ Las Vegas, Nevada
}

\section{Controlled Copy No.: Uncontrolled}

Revision No.: 1

September 1998

Approved for public release; further dissemination unlimited. 


\section{CORRECTIVE ACTION DECISION DOCUMENT/ \\ CLOSURE REPORT FOR \\ CORRECTIVE ACTION UNIT 485: \\ CACTUS SPRING PU AND DU SITE, \\ TONOPAH TEST RANGE, NEVADA}
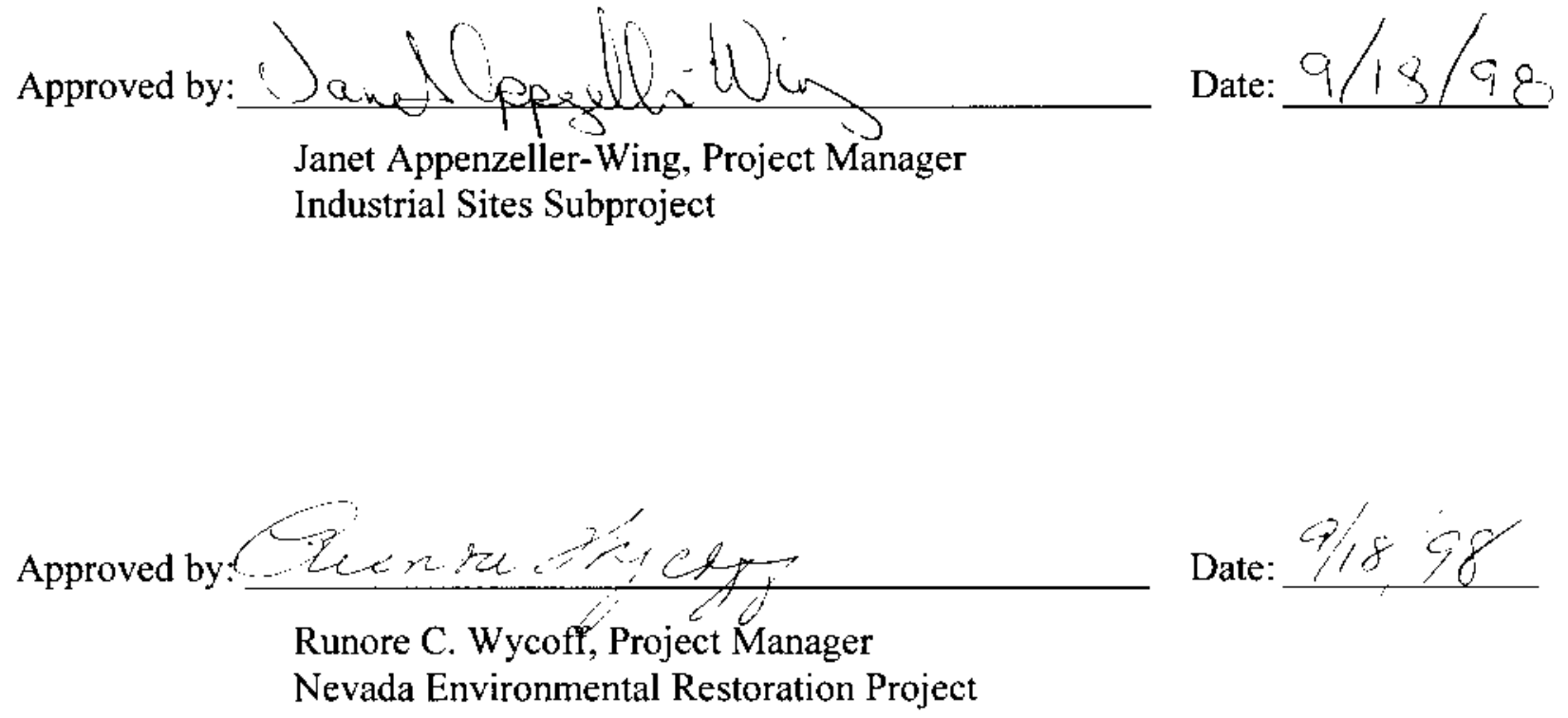


\section{Table of Contents}

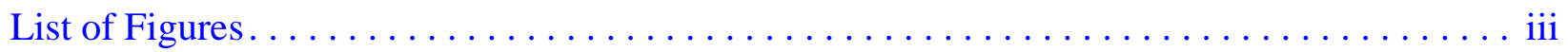

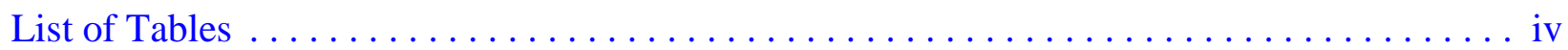

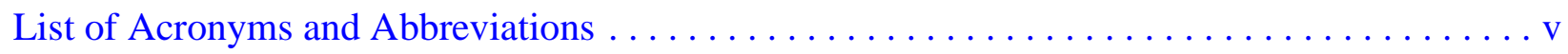

Executive Summary . . . . . . . . . . . . . . . . . . . . . . ES-1

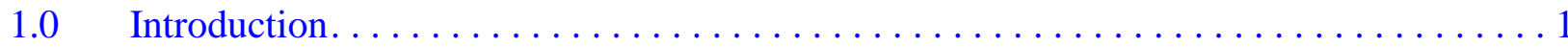

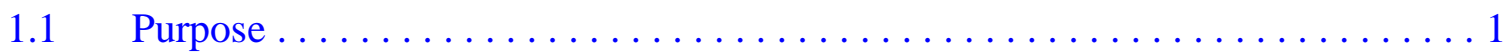

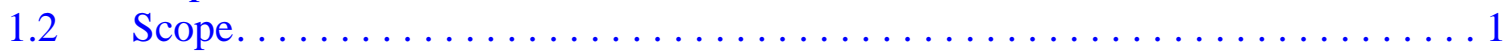

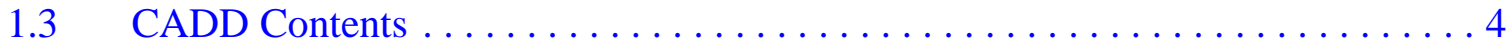

2.0 Preliminary Assessment Investigation Summary $\ldots \ldots \ldots \ldots \ldots \ldots \ldots \ldots$

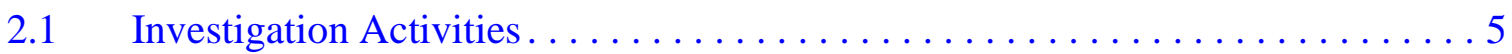

$2.2 \quad$ Results. . . . . . . . . . . . . . . . . . . . . . 6

$2.3 \quad$ Need for Corrective Action. . . . . . . . . . . . . . . . . . 6

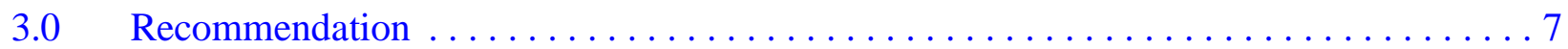

$4.0 \quad$ References................................... 8

Appendix A - Preliminary Assessment Investigation Report for CAU 485: Cactus Spring Ranch Pu and DU Site, TTR

A.1.0 Introduction. . . . . . . . . . . .

A.1.1 Project Objectives . . . . . . . . . . . . . . . .

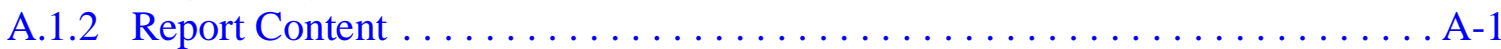

A.2.0 Field Investigation and Sampling Activities. . . . . . . . . . . . . A-3

A.2.1 Site Description and Conditions . . . . . . . . . . . . . . . A

A.2.2 Surface Radiological Surveys . . . . . . . . . . . . . . . . . . A-3

A.2.3 COC and Sample Location Identification. . . . . . . . . . . . . . . . A-7

A.2.4 Sampling Logistics . . . . . . . . . . . . . . . . . . . . . .

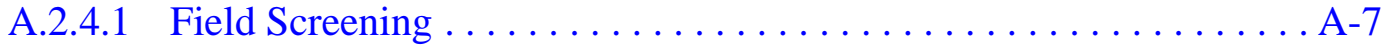

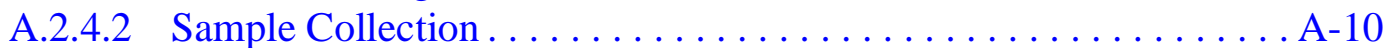

A.2.4.3 West Shed and Holding Pen . . . . . . . . . . . . . . . . . A-10

A.2.4.4 East Shed and Holding Pen.................... A-10

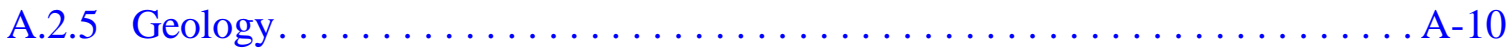

A.2.6 Hydrology ............................. A-11

A.3.0 Investigation Results. . . . . . . . . . . . . . . . 12

A.3.1 Plutonium Alpha Spectroscopy Results . . . . . . . . . . . . . . . . A-12 


\section{Table of Contents (Continued)}

A.4.0 Quality Assurance.............................. A-15

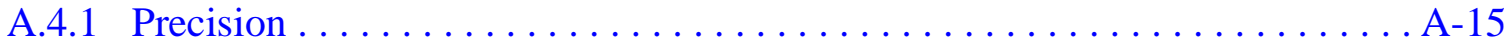

A.4.2 Accuracy ................................ A 15

A.4.3 Representativeness . . . . . . . . . . . . . . . . . . . A-16

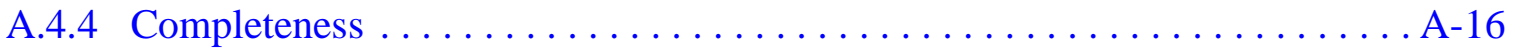

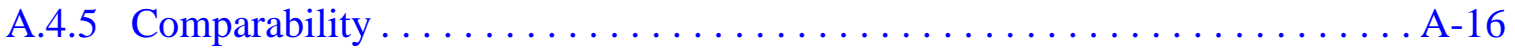

A.4.6 Tier I and Tier II Data Evaluations . . . . . . . . . . . . . . A-17

A.4.6.1 Tier I Evaluation . . . . . . . . . . . . . . . . . A $\ldots \ldots \ldots$

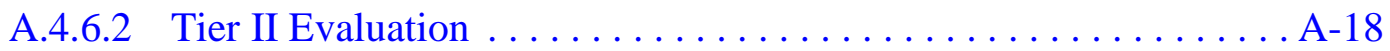

A.4.6.3 Tier III . . . . . . . . . . . . . . . . . . . . . . . . . A-18

A.4.7 Quality Control Samples. . . . . . . . . . . . . . . . . . . . . A-19

A.4.7.1 Field Quality Control Samples . . . . . . . . . . . . . . . A-19

A.4.7.2 Laboratory Quality Control Samples . . . . . . . . . . . . . . A-20

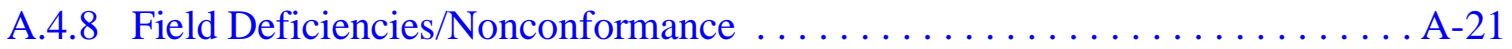

A.5.0 Summary. .................................. A-22

A.6.0 References................................. A-23

Appendix B - Nevada Environmental Restoration Project

Document Review Sheet . . . . . . . . . . . . . . . . . . . . . . . . B-1 


\section{List of Figures}

Number

1-1 Tonopah Test Range Location Map $\ldots \ldots \ldots \ldots \ldots \ldots \ldots \ldots \ldots \ldots \ldots \ldots \ldots \ldots$

1-2 Location of Cactus Spring Ranch, Tonopah Test Range .............. 3

A.2-1 CAU 485: Cactus Spring Ranch Site, Tonopah Test Range . . . . . . . . . . A-4

A.2-2 CAU 485, Cactus Spring Ranch, West (Sheep) Shed and Holding Pen, Radiological Survey Measurements ...................... A-5

A.2-3 CAU 485, Cactus Spring Ranch, East (Burro) Shed and Holding Pen, Radiological Survey Measurements .................... A-6

A.2-4 CAU 485, Cactus Spring Ranch, West (Sheep) Shed and Holding Pen, Analytical Sample Locations . . . . . . . . . . . . . . . . . . . A 8

A.2-5 CAU 485, Cactus Spring Ranch, East (Burro) Shed and Holding Pen, Analytical Sample Locations . . . . . . . . . . . . . . . . . . . . . 


\section{List of Tables}

Number

A.3-1 Radiological Analysis Results Using Method NAS-NS-3058 . . . . . . . . . . . A-13 


\section{List of Acronyms and Abbreviations}

\begin{tabular}{|c|c|}
\hline CADD & Corrective Action Decision Document \\
\hline CAIP & Corrective Action Investigation Plan \\
\hline CAS & Corrective Action Site \\
\hline CAU & Corrective Action Unit \\
\hline CLP & Contract Laboratory Program \\
\hline $\mathrm{cm}$ & Centimeter(s) \\
\hline $\mathrm{COA}$ & Certificate(s) of Analysis \\
\hline $\mathrm{COC}$ & Contaminant(s) of concern \\
\hline CR & Closure Report \\
\hline DCG & Derived Concentration Guide \\
\hline DOE & U.S. Department of Energy \\
\hline $\mathrm{DOE} / \mathrm{NV}$ & U.S. Department of Energy, Nevada Operations Office \\
\hline DU & Depleted uranium \\
\hline EDT & Electronic data transfer \\
\hline EPA & U.S. Environmental Protection Agency \\
\hline FIDLER & Field Instrument for Detecting Low Energy Radiation \\
\hline FFACO & Federal Facility Agreement and Consent Order \\
\hline in. & $\operatorname{Inch}(\mathrm{es})$ \\
\hline IT & IT Corporation \\
\hline $\mathrm{km}$ & Kilometer(s) \\
\hline LCS & Laboratory Control Sample \\
\hline MDC & Minimum detectable concentration(s) \\
\hline $\mathrm{mi}$ & Mile(s) \\
\hline
\end{tabular}




\section{List of Acronyms and Abbreviations (Continued)}

NDEP Nevada Division of Environmental Protection

NIST National Institute for Standard and Technology

ORERP Off-site Radiation Exposure Review Project

PA Preliminary Assessment

PARCC Precision, accuracy, representativeness, completeness, and comparability

$\mathrm{pCi} / \mathrm{g} \quad$ Picocurie(s) per gram

$\mathrm{pCi} / \mathrm{L} \quad$ Picocurie(s) per liter

$\mathrm{Pu} \quad$ Plutonium

${ }^{238} \mathrm{Pu} \quad$ Plutonium-238

${ }^{239 / 240} \mathrm{Pu} \quad$ Plutonium-239/240

QA Quality assurance

QAPP Quality Assurance Project Plan

QC Quality control

RPD Relative percent difference

SDG Sample delivery group

TTR Tonopah Test Range 


\section{Executive Summary}

This Corrective Action Decision Document (CADD)/Closure Report (CR) has been prepared for Corrective Action Unit (CAU) 485: Cactus Spring Ranch Plutonium (Pu) and Depleted Uranium (DU) Site, in accordance with the Federal Facility Agreement and Consent Order (FFACO) of 1996 (FFACO, 1996). The CADD and CR have been combined into one report because sample data collected during preliminary assessment activities showed no evidence of contamination at the site. This CADD/CR provides or references the specific information necessary to recommend no further actions are necessary for CAU 485 which consists of Corrective Action Site (CAS) No. TA-39-001-TAGR.

The scope of this CADD/CR is to justify and recommend that no corrective action is required at CAU 485. To achieve this scope the following actions are required:

- Review the current site conditions, including the nature and extent of contamination.

- Document closure of the CAU.

In January and February 1998, a preliminary assessment investigation was performed that consisted of activities described in the Preliminary Assessment (PA) for CAU 485: Cactus Spring Ranch Pu and DU Site Report (IT, 1998) (Note: Nevada Division of Environmental Protection [NDEP] has accepted and considers the PA Report to be the Corrective Action Investigation Plan [CAIP] for this site [NDEP, 1998]). The purpose of the investigation was to provide sufficient information and sample analytical data to determine the appropriate corrective action strategy under the FFACO.

The preliminary assessment investigation activities determined the only potential contaminant of concern to be $\mathrm{Pu}$. Off-site laboratory analysis of soil and dung samples for plutonium alpha spectroscopy demonstrated that there is no plutonium contamination in the Cactus Spring surface soil or dung. Therefore, the U.S. Department of Energy, Nevada Operations Office provides the following recommendations:

- No further corrective action is required at CAU 485.

- No Corrective Action Plan is required. 
- A Notice of Completion to DOE/NV is requested from NDEP for the clean closure of CAU 485 (Cactus Spring Ranch Pu and DU Site [CAS No. TA-39-001-TAGR]).

- CAU 485 should be moved from Appendix III to Appendix IV of the FFACO.

No use restrictions are required to be placed on the CAU because the investigation showed no evidence of contamination at the site. 


\subsection{Introduction}

This Corrective Action Decision Document (CADD)/Closure Report (CR) has been prepared for Corrective Action Unit (CAU) 485: Cactus Spring Ranch Plutonium (Pu) and Depleted Uranium (DU) Site, in accordance with the Federal Facility Agreement and Consent Order (FFACO) of 1996 that was agreed to by the U.S. Department of Energy, Nevada Operations Office (DOE/NV); the Nevada Division of Environmental Protection (NDEP); and the U.S. Department of Defense (FFACO, 1996). The CADD and CR have been combined into one report because sample data collected during preliminary assessment activities showed no evidence of contamination at the site. This CADD/CR provides or references the specific information necessary to recommend no further actions are necessary for CAU 485 which consists of Corrective Action Site (CAS) No. TA-39-001-TAGR.

Corrective Action Unit 485 is located at the Tonopah Test Range (TTR), Nevada. The TTR is approximately 255 kilometers (km) (140 miles [mi]) northwest of Las Vegas, Nevada. Cactus Spring Ranch is located approximately $10 \mathrm{~km}(6 \mathrm{mi})$ southwest of the TTR Area 3 Compound at the eastern mouth of Sleeping Column Canyon in the Cactus Range (Figure 1-1 and Figure 1-2).

\subsection{Purpose}

This CADD/CR provides justification for the clean closure of CAU 485 without further action. This justification is based on process knowledge and the results of investigative activities described in the Preliminary Assessment (PA) Report (IT, 1998).

\subsection{Scope}

The scope of this CADD/CR is to justify and recommend that no corrective action is required at CAU 485. To achieve this scope the following actions are required:

- Review the current site conditions, including the nature and extent of contamination.

- Document closure of the CAU. 


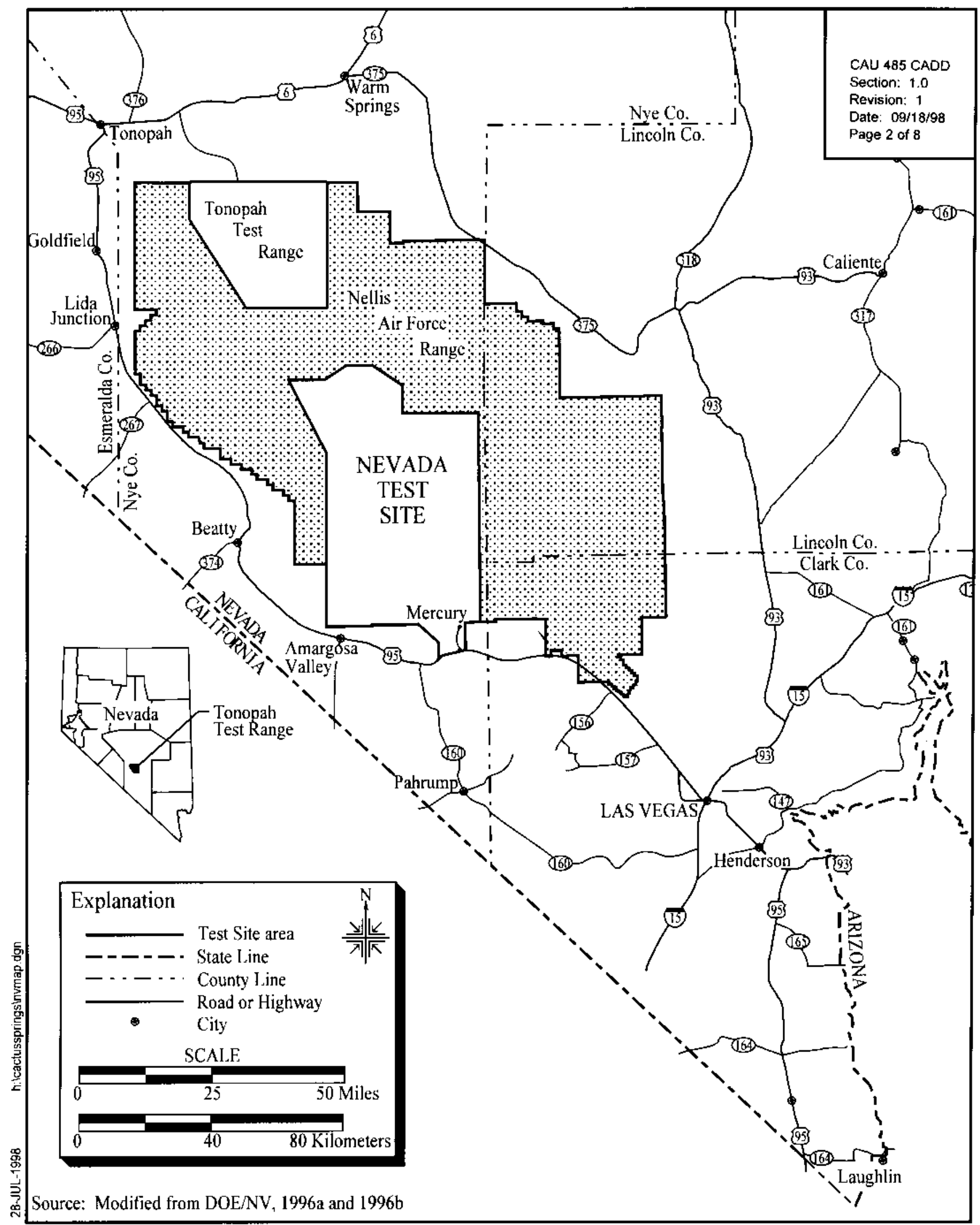

Figure 1-1

Tonopah Test Range Location Map 


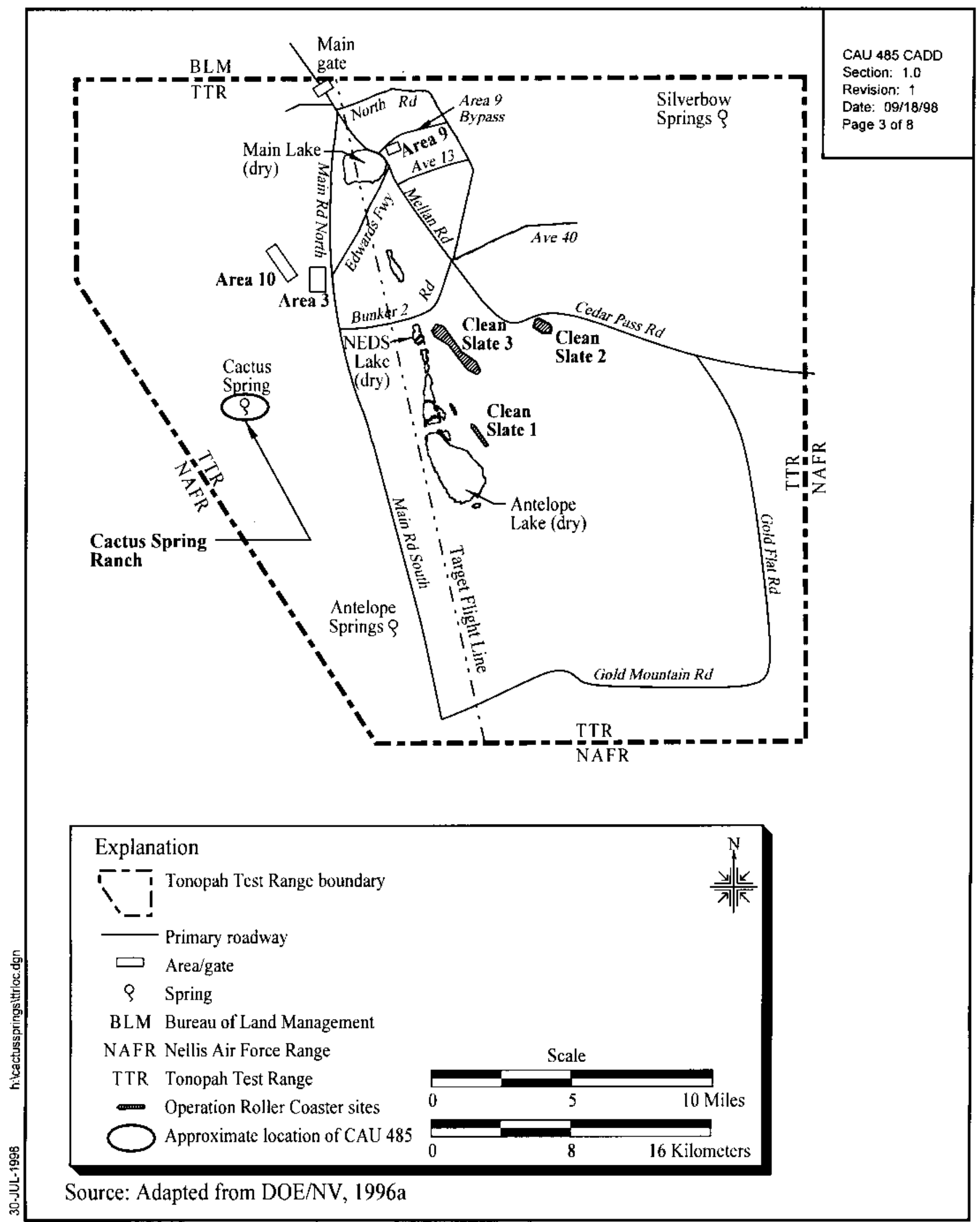

Figure 1-2

Location of Cactus Spring Ranch, Tonopah Test Range 


\section{$1.3 \quad C A D D$ Contents}

This CADD is divided into the following sections:

Section 1.0 - Introduction: summarizes the purpose, scope, and contents of this CADD

Section 2.0 - Preliminary Assessment Investigation Summary: summarizes the investigation field activities, the results of the investigation, and the need for corrective action

Section 3.0 - Recommendation: recommends that no further action be taken and the CAU be clean closed

Section 4.0 - References: provides a list of all referenced documents

Appendix A: Preliminary Assessment Investigation Report for CAU 485: Cactus Spring Ranch Pu and DU Site, TTR

Appendix B: Nevada Environmental Restoration Project Document Review Sheet

All work was performed in accordance with the following documents (Note: NDEP has accepted and considers the PA Report to be the Corrective Action Investigation Plan [CAIP] for this site [NDEP, 1998]):

- Preliminary Assessment for CAU 485: Cactus Spring Ranch Pu and DU Site, CAS No. TA-39-001-TAGR: Soil Contamination, Tonopah Test Range, Nevada (IT, 1998)

- Industrial Sites Quality Assurance Project Plan (QAPP) (DOE/NV, 1996b)

- Corrective Action Unit Work Plan, Tonopah Test Range, Nevada (DOE/NV, 1996a)

- $\quad$ FFACO (1996)

- Project Management Plan (DOE/NV, 1994) 


\subsection{Preliminary Assessment Investigation Summary}

The following sections describe and summarize the results of the investigation activities conducted at CAU 485. For detailed investigation results, please refer to Appendix A or to the PA Report (IT, 1998). The ranch housed sheep and burros used to test inhalation uptake from atmospheric releases of $\mathrm{Pu}$ and DU. The CAU is listed in the FFACO because concerned parties believed $\mathrm{Pu}$ and DU may be present at levels significantly above background levels in the surface soil and/or the remaining animal dung within the holding pens which housed the sheep and burros.

These animals were sacrificed after the tests. The location of the animals' carcasses has not been determined. Process knowledge does not indicate that the carcasses would be found within CAU 485; therefore, CAU 485 was not concerned with these carcasses. If process knowledge is identified that requires further environmental investigation at Cactus Spring Ranch, the site may be assigned new CAU and CAS designations.

\section{$2.1 \quad$ Investigation Activities}

In January and February 1998, a preliminary assessment investigation was performed that consisted of activities described in the PA Report (IT, 1998). The purpose of the investigation was to provide sufficient information and sample analytical data to determine the appropriate corrective action strategy under the FFACO. The following tasks were completed in a three-phase investigation to accomplish this purpose:

- Obtained qualitative data with respect to the surface activities of alpha, beta, and gamma-emitting radionuclides using field instruments

- Evaluated the results of the surface radiological survey, historical documents, interviews, and process knowledge to determine potential contaminants of concern (COCs) and sampling locations

- Collected 14 surface samples of the soil and dung for laboratory analysis to determine quantitatively whether plutonium was present at levels significantly above background levels

The samples obtained for laboratory analysis were field-screened for alpha and beta emitters. All samples were analyzed by an off-site laboratory using Plutonium Alpha Spectroscopy (IT, 1998). 


\subsection{Results}

The preliminary assessment investigation results are as follows:

- Surface radiological survey results indicated activities of alpha, beta, and gamma-emitting radionuclides were within the range of typical background levels.

- Evaluation of process knowledge determined plutonium to be the only potential COC. Two sampling locations were identified within each of the animal holding areas where alpha, beta, and gamma-emitting radionuclides had the highest activities.

- $\quad$ The soil and dung samples were not positive for plutonium-238 $\left({ }^{238} \mathrm{Pu}\right)$.

- Only two samples had positive concentrations of plutonium-239/240 $\left({ }^{239 / 240} \mathrm{Pu}\right)$. These concentrations were not statically greater than their sample-specific minimum detectable concentrations (MDC).

Details of the methods used and results found during the investigation are presented in Appendix A. The plutonium alpha spectroscopy results demonstrate that there is no plutonium contamination in the Cactus Spring surface soil or dung.

\subsection{Need for Corrective Action}

Analytes detected during the preliminary assessment investigation were evaluated to determine potential COCs for CAU 485. This evaluation identified no constituents above naturally occurring background levels (McArthur and Miller, 1989); therefore, no COCs were identified and there is no contamination in the CAU's surface soil or dung. No actions will be required to address contaminants at CAU 485. 


\subsection{Recommendation}

Based on the results of the preliminary assessment investigation discussed in Appendix A, no COCs have been identified at the site. Therefore, DOE/NV provides the following recommendations:

- No further corrective action is required at CAU 485.

- No Corrective Action Plan is required.

- A Notice of Completion to DOE/NV is requested from NDEP for the clean closure of CAU 485 (Cactus Spring Ranch Pu and DU Site [CAS Number TA-39-001-TAGR]).

- CAU 485 should be moved from Appendix III to Appendix IV of the FFACO.

No use restrictions are required to be placed on the CAU because the investigation showed no evidence of contamination at the site. 


\subsection{References}

DOE/NV, see U.S. Department of Energy, Nevada Operations Office.

FFACO, see Federal Facility Agreement and Consent Order.

Federal Facility Agreement and Consent Order. 1996. Agreed to by the State of Nevada, the U.S. Department of Energy, and the U.S. Department of Defense.

IT, see IT Corporation.

IT Corporation. 1998. Preliminary Assessment for CAU 485: Cactus Spring Ranch Pu and DU Site, CAS No. TA-39-001-TAGR: Soil Contamination, Tonopah Test Range, Nevada. Las Vegas, NV.

McArthur, R.D., and F.L. Miller, Jr. 1989. Off-site Radiation Exposure Review Project (ORERP), Phase II Soil Program, DOE/NV/10384-23. Las Vegas, NV: Desert Research Institute.

NDEP, see State of Nevada Division of Environmental Protection.

State of Nevada Division of Environmental Protection. 1998. Letter from Paul Liebendorfer of NDEP to Runore Wycoff of DOE/NV regarding "Preliminary Assessment Report for Corrective Action Unit 485, Cactus Spring Ranch Pu and DU Site, Tonopah Test Range," 24 April. Carson City, NV.

U.S. Department of Energy, Nevada Operations Office. 1994. Project Management Plan. Las Vegas, NV.

U.S. Department of Energy, Nevada Operations Office. 1996a. Corrective Action Unit Work Plan, Tonopah Test Range, Nevada, DOE/NV-426. Las Vegas, NV: IT Corporation.

U.S. Department of Energy, Nevada Operations Office. 1996b. Industrial Sites Quality Assurance Project Plan, DOE/NV-425. Las Vegas, NV. 


\section{Appendix A}

\section{Preliminary Assessment Investigation Report for CAU 485: Cactus Spring Ranch Pu and DU Site, TTR}




\section{A.1.0 Introduction}

The following report presents a summary of investigation activities and analytical results from the preliminary assessment investigation conducted at CAU 485: Cactus Spring Ranch Pu and DU Site located at the TTR (see Figure 1-1 of the CADD/CR). The CAU is comprised of CAS TA-39-001-TAGR (FFACO, 1996) which housed sheep and burros used to test inhalation uptake from atmospheric releases of plutonium and depleted uranium. The preliminary assessment investigation was conducted in accordance with the PA Report (IT, 1998). The PA Report is accepted and considered to be the Corrective Action Investigation Plan for CAU 485 by NDEP (NDEP, 1998).

Additional information regarding the site history, planning, and scope of the investigation is also presented in the PA Report (IT, 1998) and will not be repeated in this report.

\section{A.1.1 Project Objectives}

The primary objective of the investigation was to obtain qualitative and quantitative data to determine if plutonium was present at levels significantly above background levels in the surface soil and/or the remaining animal dung within the holding pens that housed the sheep and burros.

\section{A.1.2 Report Content}

This report will provide information and data in sufficient detail to support the clean closure of CAU 485 with no further action. The contents of this report are as follows:

- Section A.1.0 describes the investigation background, objectives, and the report content.

- Section A.2.0 provides information regarding the field activities and sampling methods.

- Section A.3.0 summarizes the results of the laboratory analysis from the investigation sampling.

- Section A.4.0 discusses the quality assurance (QA) and quality control (QC) procedures that were followed and the results of the QA/QC activities. 
- Section A.5.0 is a summary of the investigation results for CAU 485 Cactus Spring Ranch.

- Section A.6.0 provides the cited references.

The complete field documentation and laboratory data, including Field Activity Daily Logs, Sample Collection Logs, Analysis Request/Chain-of-Custody Forms, laboratory certificates of analyses, and analytical results are retained in project files as hard copy files and/or electronic media. 


\section{A.2.0 Field Investigation and Sampling Activities}

The field investigation and sampling activities were conducted in three phases at CAU 485. The first phase consisted of a surface radiological survey of the sheds and holding pens. In the second phase, the results of the surface radiological survey, historical documents, interviews, and process knowledge were evaluated to determine potential COCs and sampling locations. The third phase consisted of collecting surface samples from locations of highest alpha, beta, and gamma-emitting activities identified in the second phase. Some additional sampling locations were selected during the investigation.

\section{A.2.1 Site Description and Conditions}

Cactus Spring Ranch is located approximately $9.7 \mathrm{~km}(6 \mathrm{mi})$ southwest of the Area 3 Compound at the eastern mouth of Sleeping Column Canyon in the Cactus Range on the TTR. The areas of concern at the CAU are the sheds and holding pens that housed the sheep and burros (Figure A.2-1).

\section{A.2.2 Surface Radiological Surveys}

A surface radiological survey was conducted at the sheds and holding pens of the CAU by IT Corporation (IT) personnel in January 1998. The surface was surveyed using a Field Instrument for Detecting Low Energy Radiation (FIDLER) probe and an NE Technology “Electra” alpha/beta survey instrument.

The results of the survey were plotted as contours. These results and the methodology used for obtaining these results can be found in the PA Report (IT, 1998). The raw data obtained during the survey are presented in Figure A.2-2 and Figure A.2-3.

Although the results of this survey revealed that activities of alpha, beta, and gamma-emitting radionuclides were within the range of typical background levels, trends in the data did reveal that some areas within the sheds and holding pens had slightly higher activities than others (IT, 1998). 


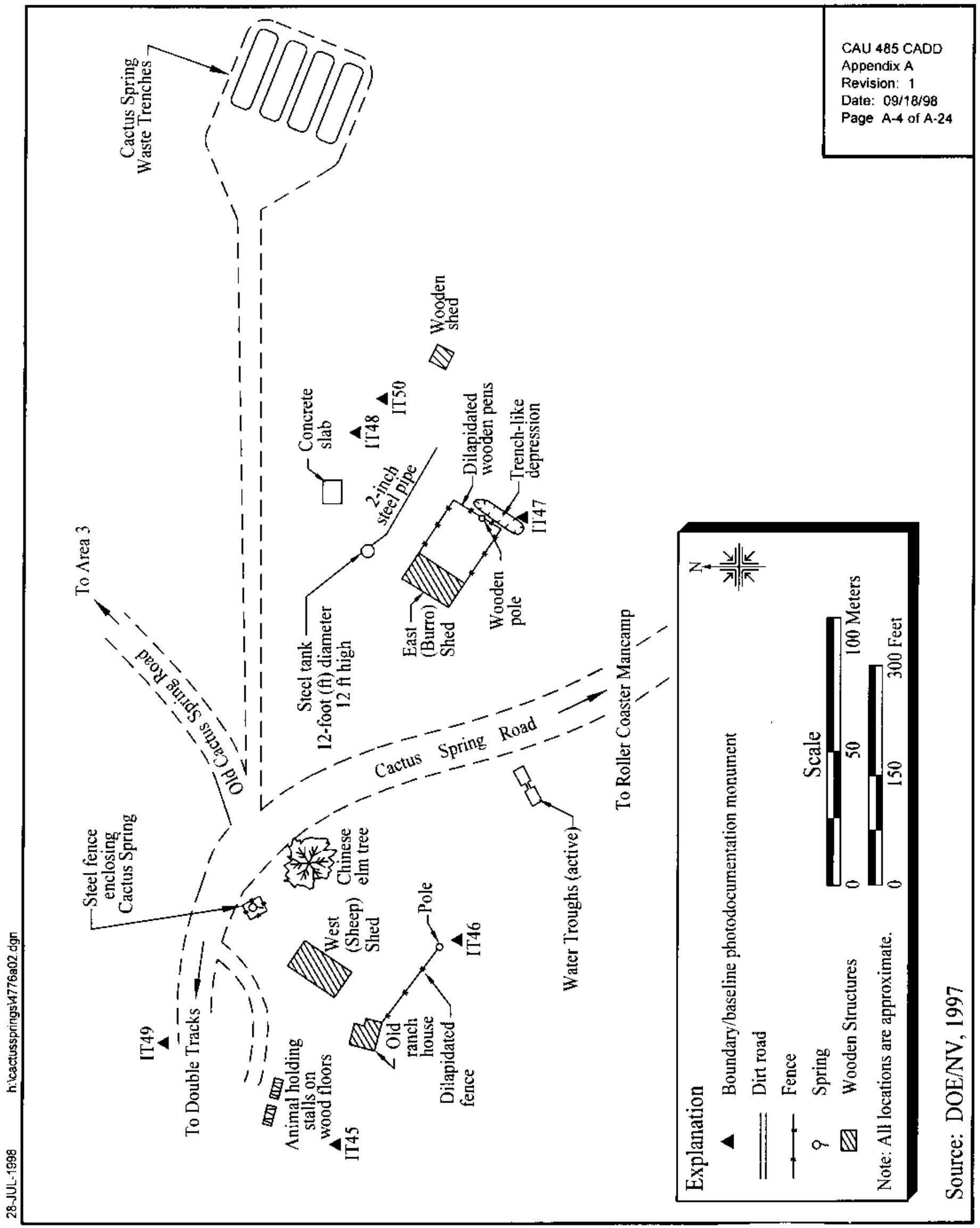

Figure A.2-1

CAU 485: Cactus Spring Ranch Site, Tonopah Test Range 


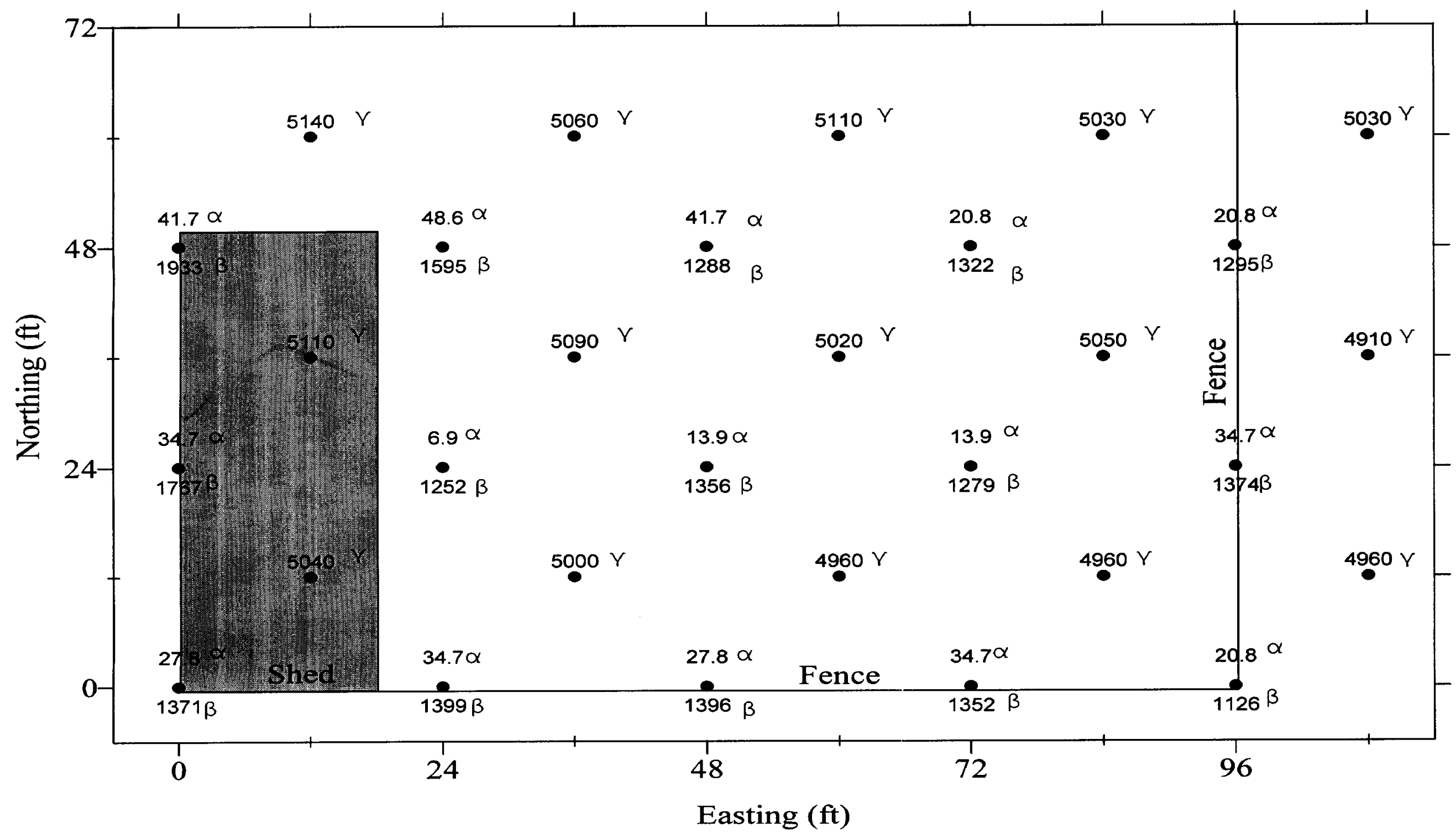

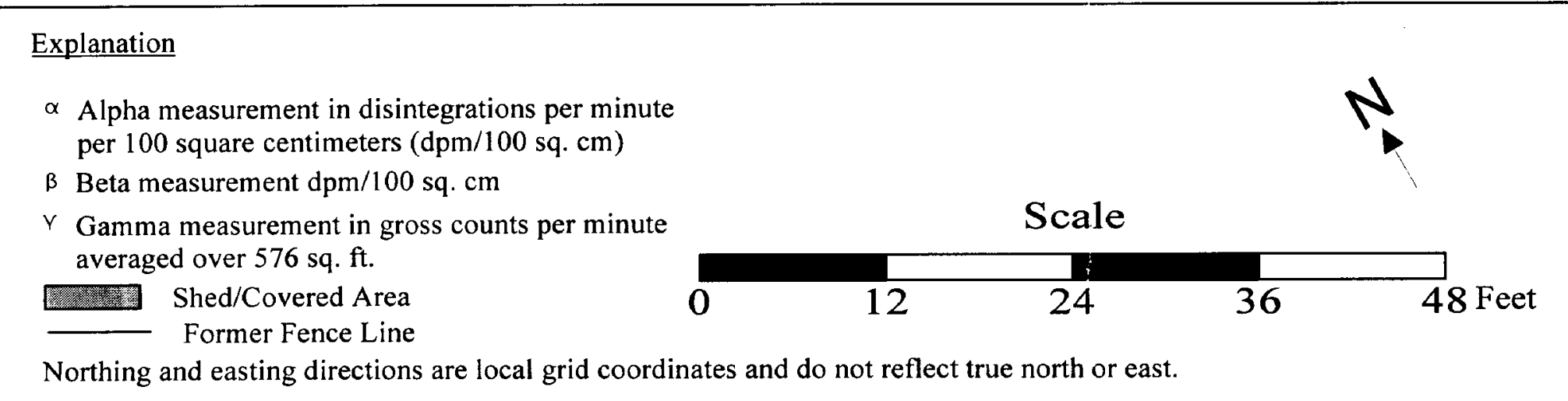




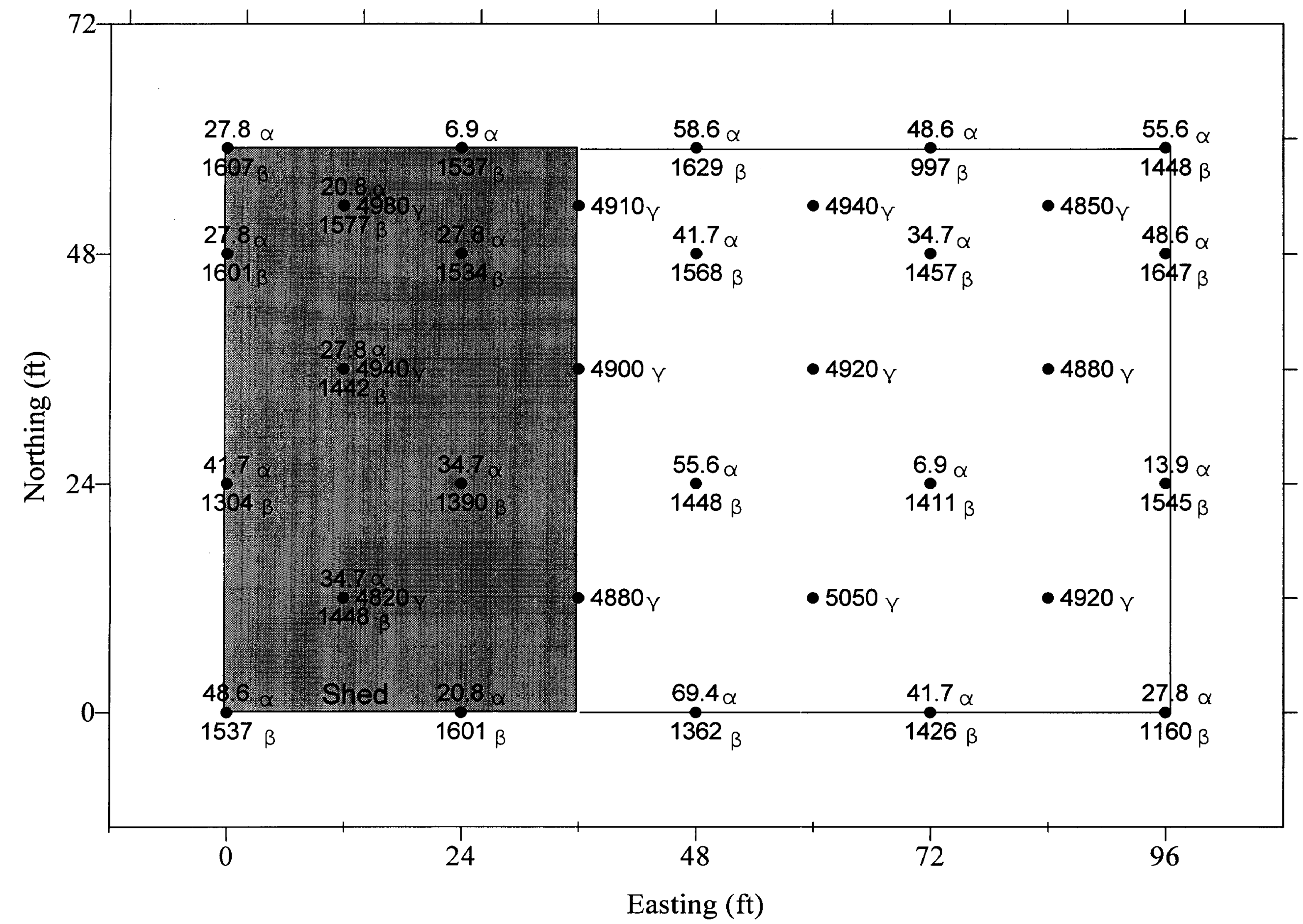

Explanation

$\alpha$ Alpha measurement in disintegrations per minute

per 100 square centimeters $(\mathrm{dpm} / 100 \mathrm{sq} . \mathrm{cm})$

$N$

$\beta$ Beta measuremen $\mathrm{dpm} / 100 \mathrm{sq} . \mathrm{cm}$

$\checkmark$ Gamma measurement in gross counts per minute

Shed/ Covered Area 


\section{A.2.3 COC and Sample Location Identification}

The only known radiological source term at the CAU is the Pu excreted in the urine and feces of the sheep and burros while they were on site, and the Pu that could have collected on their coats and fell off onto the surface soil. Any DU from the animals that may have contributed to the concentration of DU at the CAU would not be distinguishable from the much higher natural concentration of uranium-238 found in soil. Therefore, the only potential COC at CAU 485 is $\mathrm{Pu}$.

Two sample locations were chosen within each of the two animal holding areas based on the trends generated using the raw data obtained in the surface radiological survey.

\section{A.2.4 Sampling Logistics}

Once on site, the Site Supervisor chose two additional sample locations within each of the animal holding areas where dung was present to ensure that dung was sampled. If dung was present at a sample location, then it was sampled from its uppermost surface to the dung/soil interface. A separate sample was then collected from the dung/soil interface to an approximate depth of 15 centimeters $(\mathrm{cm})(6$ inches [in.]) within the soil. If dung was not present at the sample location, then a surface sample was collected from the surface to a depth of approximately $15 \mathrm{~cm}(6 \mathrm{in}$.). All samples were collected using disposable sampling scoops, a split-spoon and slide hammer, and a stainless steel bowl.

The sample locations, as shown on Figure A.2-4 and Figure A.2-5, are identified by "local grid coordinates." The southwest corners of the sheds at the holding pens were used as the origins for the local grid layouts.

\section{A.2.4.1 Field Screening}

All samples were field-screened for alpha and beta radiation using the Electra instrument before they were containerized. The preliminary action level for radiation monitoring results was established at two times background levels. None of the samples collected indicated activities greater than twice background. 


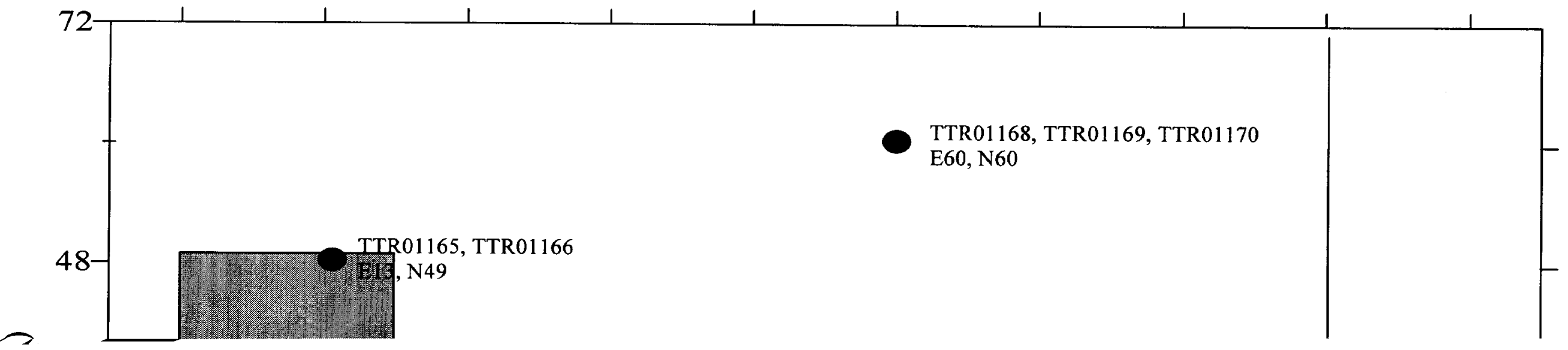




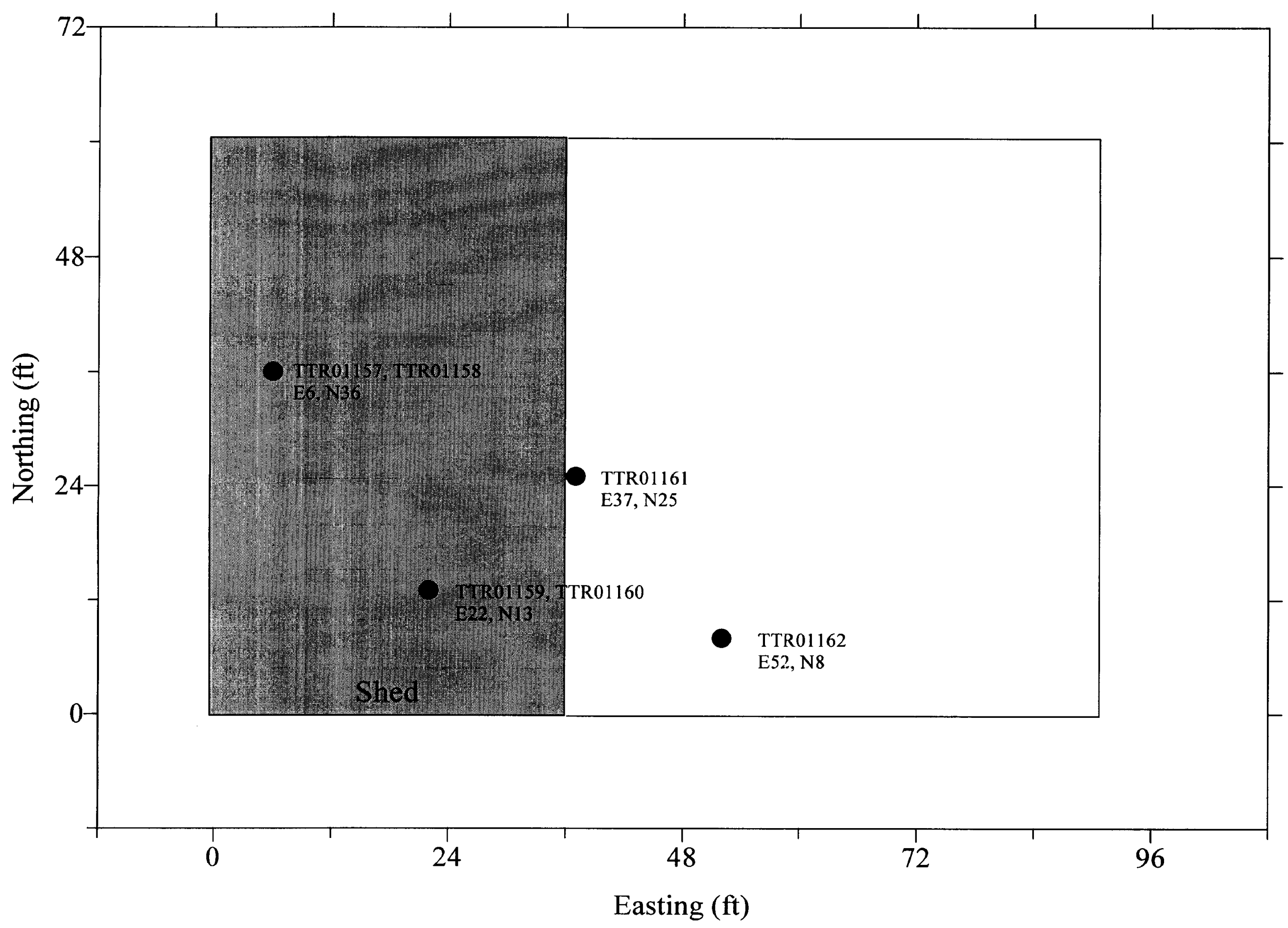

\begin{tabular}{l}
\hline Sxplanation \\
\hline \\
\hline
\end{tabular}




\section{A.2.4.2 Sample Collection}

Sample collection was performed in accordance with the PA Report (IT, 1998) and the Industrial Sites Quality Assurance Project Plan (QAPP) (DOE/NV, 1996b).

\section{A.2.4.3 West Shed and Holding Pen}

The west shed and holding pen are located on the western side of Cactus Spring Ranch (Figure A.2-1). Eight samples were collected from four locations. Local grid coordinates E13, N49 and E60, N60 were selected for sampling based on the surface radiological survey. Sample numbers TTR01165 and TTR01166 were collected at E13, N49. Sample numbers TTR01168, TTR01169, and TTR01170 were collected at E60, N60. Sample number TTR01167 was collected at E17, N-19 due to a suspected dung mound at this location. Sample numbers TTR01163 and TTR01164 were collected at E4, N4 to obtain a dung sample and a surface soil sample below the visible dung (Figure A.2-4).

\section{A.2.4.4 East Shed and Holding Pen}

The east shed and holding pen are located on the eastern side of Cactus Spring Ranch (Figure A.2-1). Six samples were collected from four locations. Local grid coordinates E37, N25 and E52, N8 were selected for sampling based on the surface radiological survey. Sample number TTR01161 was collected at E37, N25 and sample number TTR01162 was collected at E52, N8. The other two locations were chosen at E6, N36 and E22, N13 to obtain dung samples. Sample numbers TTR01157 and TTR01158 were collected at local grid coordinate E6, N36 and sample numbers TTR01159 and TTR01160 were collected at E22, N13 (Figure A.2-5).

\section{A.2.5 Geology}

A surface trace of a major northwest-southeast trending fault appears to pass through Cactus Spring. The general area consists of thick sequences of conglomerate, quartzite, and limestone as well as brecciated limestone to the southwest (IT, 1998). 


\section{A.2.6 Hydrology}

The topography slopes gently to the east with surface drainage flowing in the same direction. Two springs are located at the Cactus Spring Ranch Site where groundwater is discharged to the surface. An inferred, down-to-the-east normal fault may yield greater depths to groundwater at the eastern edge of the site (IT, 1998). 


\section{A.3.0 Investigation Results}

The analytical results of samples collected from the Cactus Spring Ranch CAU have been compiled and evaluated to determine the presence of contamination. The analytical results are summarized in the following subsections. The complete laboratory results data packages are available in the project files.

During the investigation activities, 14 soil and dung samples and 2 liquid samples were collected for laboratory analysis. The sample locations, numbers, depths, and results are presented in Table A.3-1. The samples were analyzed using laboratory analytical method NAS-NS-3058 (National Academy of Sciences, 1965) for ${ }^{238} \mathrm{Pu}$ and ${ }^{239 / 240} \mathrm{Pu}$. The analytical parameter was selected through the application of site process knowledge according to the U.S. Environmental Protection Agency's (EPA) Guidance for the Data Quality Objectives Process (EPA, 1994). Preliminary action levels for the off-site laboratory analytical method were background levels listed in the Offsite Radiation Exposure Review Project (ORERP) Phase II Soil Programs report (McArthur and Miller, 1989) for ${ }^{238} \mathrm{Pu}$ and ${ }^{239 / 240} \mathrm{Pu}$. Documentation supporting process knowledge and other historical documentation can be found in the PA Report (IT, 1998). Sampling activities were conducted to either confirm or disprove the presence of potential COCs as identified in the second phase of this investigation. Samples collected from CAU 485 were analyzed by Quanterra Environmental Services in St. Louis, Missouri.

\section{A.3.1 Plutonium Alpha Spectroscopy Results}

The MDC for the ${ }^{238} \mathrm{Pu}$ in the soil samples varied from a low of 0.093 picocuries per gram (pCi/g) to a high of $0.16 \mathrm{pCi} / \mathrm{g}$. None of the ${ }^{238} \mathrm{Pu}$ concentrations were positive; the $2 \sigma$ counting error exceeded the measurement for every sample. The concentration of ${ }^{238} \mathrm{Pu}$ in soil at background locations has been estimated to be less than $0.002 \mathrm{pCi} / \mathrm{g}$ (McArthur and Miller, 1989).

The MDC for the ${ }^{239 / 240} \mathrm{Pu}$ concentration in the soil samples varied from a low of $0.05 \mathrm{pCi} / \mathrm{g}$ to a high of $0.15 \mathrm{pCi} / \mathrm{g}$. Two soil samples, 16988-005 and 16988-011, were positive, but were not statistically greater than their sample-specific MDC. The concentration of ${ }^{239 / 240} \mathrm{Pu}$ in soil 
Table A.3-1

Radiological Analysis Results Using Method NAS-NS-3058

\begin{tabular}{|c|c|c|c|c|c|c|c|c|c|c|c|}
\hline $\begin{array}{l}\text { Sample } \\
\text { Location }\end{array}$ & $\begin{array}{l}\text { IT Corp. } \\
\text { Sample No. }\end{array}$ & \begin{tabular}{|c|} 
Sample \\
Depth (feet)
\end{tabular} & $\begin{array}{l}\text { Laboratory } \\
\text { Sample No. }\end{array}$ & Matrix & Parameter & Result & Error & $\begin{array}{l}\text { Minimum Detectable } \\
\text { Concentration }\end{array}$ & Units & Qualifier & $\begin{array}{l}\text { Sample } \\
\text { Date }\end{array}$ \\
\hline \multirow{2}{*}{ NA } & TTR01155 & \multirow{2}{*}{ NA } & \multirow{2}{*}{$16988-001$} & \multirow{2}{*}{ Water } & Plutonium 238 & 0.018 & 0.064 & 0.17 & $\mathrm{PCl} / \mathrm{L}$ & $U$ & $16-F e b-98$ \\
\hline & Eqpt. Rinsate & & & & Plutonium 239/240 & -0.018 & 0.022 & 0.19 & $\mathrm{PCl} / \mathrm{L}$ & $\bar{U}$ & 16-Feb-98 \\
\hline \multirow{2}{*}{ NA } & TTR01156 & \multirow{2}{*}{ NA } & \multirow{2}{*}{ 16988-002 } & \multirow{2}{*}{ Water } & Plutonium 238 & 0.012 & 0.094 & 0.27 & $\overline{P C I / L}$ & $\bar{U}$ & 18-Feb-98 \\
\hline & Field Blank & & & & Plutonium 239/240 & -0.031 & 0.074 & 0.29 & $\mathrm{PCl} / \mathrm{L}$ & $\bar{U}$ & 18-Feb-98 \\
\hline \multirow{4}{*}{$\begin{array}{l}\text { East Shed } \\
\text { E6, N36 }\end{array}$} & \multirow{2}{*}{ TTR01157 } & \multirow{2}{*}{$0.0-0.25$} & \multirow{2}{*}{$16988-003$} & \multirow{2}{*}{ Dung } & Plutonium 238 & 0.028 & 0.051 & 0.10 & $\mathrm{PCl} / \mathrm{G}$ & $U$ & 18-Feb-98 \\
\hline & & & & & Plutonium 239/240 & 0.048 & 0.058 & 0.089 & $\mathrm{PCl} / \mathrm{G}$ & U & 18-Feb-98 \\
\hline & \multirow{2}{*}{ TTR01158 } & \multirow{2}{*}{$0.5-0.75$} & \multirow{2}{*}{$16988-004$} & \multirow{2}{*}{ Soil } & Plutonium 238 & -0.00002 & 0.054 & 0.15 & $\mathrm{PCl} / \mathrm{G}$ & $\bar{U}$ & 18-Feb-98 \\
\hline & & & & & Plutonium 239/240 & -0.003 & 0.032 & 0.11 & $\mathrm{PCl} / \mathrm{G}$ & $U$ & 18-Feb-98 \\
\hline \multirow{4}{*}{$\begin{array}{c}\text { East Shed } \\
\text { E22, N13 }\end{array}$} & \multirow{2}{*}{ TTR01159 } & \multirow{2}{*}{$0.0-0.25$} & \multirow{2}{*}{ 16988-005 } & \multirow{2}{*}{ Dung } & Plutonium 238 & -0.003 & 0.047 & 0.15 & $\mathrm{PCl} / \mathrm{G}$ & $\bar{U}$ & 18-Feb-98 \\
\hline & & & & & Plutonium 239/240 & 0.16 & 0.11 & 0.072 & $\mathrm{PCl} / \mathrm{G}$ & $\mathrm{U}$ & 18-Feb-98 \\
\hline & \multirow{2}{*}{ TTR01160 } & \multirow{2}{*}{$0.5-0.75$} & \multirow{2}{*}{ 16988-006 } & \multirow{2}{*}{ Soil } & Plutonium 238 & 0.074 & 0.078 & 0.12 & $\mathrm{PCl} / \mathrm{G}$ & $\bar{U}$ & 18-Feb-98 \\
\hline & & & & & Plutonium 239/240 & 0.003 & 0.033 & 0.11 & $\mathrm{PCl} / \mathrm{G}$ & $\bar{U}$ & 18-Feb-98 \\
\hline \multirow{2}{*}{$\begin{array}{l}\text { East Shed } \\
\text { E37, N25 }\end{array}$} & TTR01161 & $00-05$ & $16988-007$ & Soil & Plutonium 238 & -0.015 & 0.047 & 0.16 & $\mathrm{PCl} / \mathrm{G}$ & 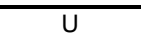 & 18-Feb-98 \\
\hline & 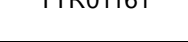 & $0.0-0.5$ & $10900-001$ & 5011 & Plutonium 239/240 & -0.012 & 0.034 & 0.13 & $\mathrm{PCl} / \mathrm{G}$ & $\bar{U}$ & 18-Feb-98 \\
\hline East Shed & TTR01162 & $0.0-0.25$ & 16988-008 & Soil & Plutonium 238 & 0.054 & 0.067 & 0.12 & $\mathrm{PCl} / \mathrm{G}$ & $\mathrm{U}$ & 18-Feb-98 \\
\hline & $1 \mathrm{TR} 01162$ & $0.0-0.25$ & $16988-008$ & Soll & Plutonium 239/240 & -0.025 & 0.029 & 0.12 & $\mathrm{PCl} / \mathrm{G}$ & $\bar{U}$ & 18-Feb-98 \\
\hline & & $0.0-0.25$ & & & Plutonium 238 & 0.036 & 0.059 & 0.12 & $\mathrm{PCl} / \mathrm{G}$ & $U$ & 18-Feb-98 \\
\hline West Shed & $1 \mathrm{TR01163}$ & $0.0-0.25$ & $16988-009$ & Dung & Plutonium 239/240 & 0.036 & 0.053 & 0.10 & $\mathrm{PCl} / \mathrm{G}$ & $\mathrm{U}$ & 18-Feb-98 \\
\hline E4, N4 & TTR01164 & $05-10$ & $16988-010$ & Soit & Plutonium 238 & 0.016 & 0.039 & 0.092 & $\mathrm{PCl} / \mathrm{G}$ & $\bar{U}$ & 18-Feb-98 \\
\hline & $11 \mathrm{RU16}$ & $0.5-1.0$ & $16988-010$ & soll & Plutonium 239/240 & 0.019 & 0.039 & 0.084 & $\mathrm{PCl} / \mathrm{G}$ & $\mathrm{U}$ & 18-Feb-98 \\
\hline & TTR01165 & $00 \Omega 25$ & 16088011 & Dung & Plutonium 238 & 0.023 & 0.044 & 0.093 & $\mathrm{PCl} / \mathrm{G}$ & $U$ & $18-F e b-98$ \\
\hline West Shed & IIR0116s & $0.0-0.25$ & $16988-011$ & Dung & Plutonium 239/240 & 0.060 & 0.053 & 0.050 & $\mathrm{PCl} / \mathrm{G}$ & $U$ & 18-Feb-98 \\
\hline $\mathrm{E} 13, \mathrm{~N} 49$ & TTR01166 & $05-10$ & $16088-012$ & Soil & Plutonium 238 & -0.011 & 0.033 & 0.13 & $\mathrm{PCl} / \mathrm{G}$ & $\bar{U}$ & 18-Feb-98 \\
\hline & 11 RUणा00 & $0.0-1.0$ & $10900-012$ & 5011 & Plutonium 239/240 & -0.011 & 0.046 & 0.15 & $\mathrm{PCl} / \mathrm{G}$ & $\bar{U}$ & $18-F e b-98$ \\
\hline West Shed & TTR01167 & $00-075$ & $16988-013$ & Soil & Plutonium 238 & 0.013 & 0.041 & 0.10 & $\mathrm{PCl} / \mathrm{G}$ & $\mathrm{U}$ & 18-Feb-98 \\
\hline $\mathrm{E} 17, \mathrm{~N}-19$ & IIRUTा6/ & $0.0-0.15$ & $16988-013$ & Soll & Plutonium 239/240 & -0.025 & 0.016 & 0.11 & $\mathrm{PCl} / \mathrm{G}$ & $\mathrm{U}$ & 18-Feb-98 \\
\hline & & $00-025$ & & & Plutonium 238 & -0.021 & 0.038 & 0.14 & $\mathrm{PCl} / \mathrm{G}$ & $\bar{U}$ & 18-Feb-98 \\
\hline & TTR01168 & $0.0-0.25$ & 16988-014 & Dung & Plutonium 239/240 & 0.014 & 0.049 & 0.12 & $\mathrm{PCl} / \mathrm{G}$ & $U$ & $18-F e b-98$ \\
\hline & TTR01169 & & & Soil & Plutonium 238 & 0.014 & 0.043 & 0.10 & $\mathrm{PCl} / \mathrm{G}$ & $\mathrm{U}$ & 18-Feb-98 \\
\hline $\mathrm{E} 60, \mathrm{~N} 60$ & IIR01169 & $0.5-0.15$ & $16988-015$ & Soll & Plutonium 239/240 & 0.012 & 0.035 & 0.086 & $\mathrm{PCl} / \mathrm{G}$ & $\mathrm{U}$ & 18-Feb-98 \\
\hline & & & & & Plutonium 238 & 0.022 & 0.043 & 0.094 & $\mathrm{PCl} / \mathrm{G}$ & $\mathrm{U}$ & 18-Feb-98 \\
\hline & Field Duplicate & $0.0-0.25$ & 16988-016 & Dung & Plutonium 239/240 & 0.055 & 0.061 & 0.099 & $\mathrm{PCl} / \mathrm{G}$ & $U$ & 18-Feb-98 \\
\hline
\end{tabular}


samples taken from background locations is less than $0.19 \mathrm{pCi} / \mathrm{g}$ (McArthur and Miller, 1989). The plutonium alpha spectroscopy results demonstrate that there is no plutonium contamination in Cactus Spring soil. 


\section{A.4.0 Quality Assurance}

The results of QA/QC activities for the Cactus Spring Ranch Preliminary Assessment Investigation sampling event are summarized in the following text. Detailed information on the QA program for this sampling event is contained in the Industrial Sites QAPP (DOE/NV, 1996b).

Quality control results are typically judged in terms of the five precision, accuracy, representativeness, completeness, and comparability (PARCC) parameters as described in the following sections.

\section{A.4.1 Precision}

Precision is a quantitative measure of the variability of a group of measurements from their average value. Precision is assessed by collecting and analyzing duplicate field samples and comparing the results with the original sample. Precision is also assessed by creating, analyzing, and comparing laboratory duplicates from one or more field samples. Precision is reported as relative percent difference (RPD) which is calculated as the difference between the measured concentrations of duplicate samples, divided by the average of the two concentrations, and multiplied by 100 .

\section{A.4.2 Accuracy}

Analytical accuracy is defined as the nearness of a measurement to the true or accepted reference value. It is the composite of the random and systematic components of the measurement system and measures bias in the measurement system. The random component of accuracy is measured and documented through the analyses of spiked samples. Sampling accuracy is assessed by evaluating the results of spiked samples and laboratory control samples. Accuracy measurements are calculated as percent recovery by dividing the measured sample concentration by the true concentration and multiplying the quotient by 100 .

Field accuracy is assessed by confirming that the documents of record track the sample from its origin, through transfer of custody, to disposal. The goal of field accuracy is for all samples to be collected from the correct locations at the correct time, placed in a correctly labeled container with 
the correct preservative, and sealed with custody tape to prevent tampering. All samples in this sampling event were properly collected and forwarded to the laboratory as described above.

\section{A.4.3 Representativeness}

Representativeness expresses the degree to which sample data accurately and precisely represent a characteristic of a population, parameter variations at a sampling point, or an environmental condition (EPA, 1987). However, a biased sampling plan was used in this investigation to ensure samples were collected from those locations with the highest surface radiological concentrations (IT, 1998).

\section{A.4.4 Completeness}

Completeness is defined as a percentage of measurements made that are judged to be valid. A sampling and analytical requirement of 80 percent completeness was established for this project (DOE/NV, 1996a). The Cactus Spring Ranch sampling data exhibit a high degree of completeness. The specified sampling locations were utilized as planned. All samples were collected as specified in the PA Report (IT, 1998), and all sample containers reached the laboratory intact and properly preserved (when applicable). For all samples, sample temperature was maintained during shipment to the laboratory, and sample chain of custody was maintained during sample storage and/or shipment.

\section{A.4.5 Comparability}

Comparability is a qualitative parameter expressing the confidence with which one data set can be compared to another (EPA, 1987). To ensure comparability, the Cactus Spring Ranch field and sampling activities were performed and documented in accordance with approved procedures, and all samples were collected in accordance with the PA Report (IT, 1998). Approved standardized methods and procedures were also used to analyze and report the data (e.g., Contract Laboratory Program [CLP] and/or CLP-like data packages). This approach ensures that the data from this project can be compared to other data sets. Based on the minimum comparability requirements specified in the Industrial Sites QAPP (DOE/NV, 1996b), all requirements were met. 
Sample-handling documentation, laboratory nonconformance reports, and the precision and accuracy of quality-control sample results were evaluated for their effect on the results of the associated environmental samples. The environmental sample results were then qualified according to processes outlined in the following section. Documentation of the data qualifications resulting from these reviews is retained in project files as both hard copy and electronic media and will be supplied upon request.

\section{A.4.6 Tier I and Tier II Data Evaluations}

All laboratory data from samples collected at Cactus Spring Ranch have been evaluated for data quality according to the procedures outlined in IT-Las Vegas Standard Quality Practices (IT, 1993). These procedures, performed in a tiered process, are based upon EPA data validation guidelines and presented in the following text, resulted in modifications to the laboratory-generated qualifiers or results. No data were rejected during the data evaluation process.

The changes resulting from the data evaluation process were documented in project files and were summarized in a memorandum for the sample delivery group (SDG). This memorandum is maintained in IT project files and is available for inspection upon request.

\section{A.4.6.1 Tier I Evaluation}

Tier I evaluation for radiological analysis examines (but is not limited to):

- Sample count/type consistent with chain of custody

- Analysis count/type consistent with chain of custody

- Correct sample matrix

- Significant problems stated in cover letter or case narrative

- Completeness of certificates of analysis (COAs)

- Completeness of CLP or CLP-like packages

- Completeness of signatures, dates and times on chain of custody

- Condition-upon-receipt variance form included

- Requested analyses performed on all samples

- Date received/analyzed given for each sample

- Correct concentration units indicated

- Correct detection limits achieved

- Electronic data transfer (EDT) supplied 
- Results reported for field and laboratory QC samples

- Whether or not the deliverable met the overall objectives of the project

\section{A.4.6.2 Tier II Evaluation}

Tier II evaluation for radiological analysis examines (but is not limited to):

- Whether or not blank contamination evaluated and applied to sample results/qualifiers

- Whether or not the COA is consistent with data package documentation

- QC sample results (duplicates, laboratory control samples, matrix spikes and matrix spike duplicates) evaluated and applied to laboratory result qualifiers

- Whether or not sample results, error, and minimum detectable activity evaluated and applied to laboratory result qualifiers

- Whether or not the detector system was calibrated to National Institute for Standards and Technology (NIST) traceable sources

- Whether or not calibration sources preparation was documented, demonstrating proper preparation and appropriateness for sample matrix, emission energies, and concentrations

- Detector system response to daily, weekly, and monthly background and calibration checks for peak energy, peak centroid, peak full width half maximum, and peak efficiency

- Whether or not tracers were NIST-traceable, were appropriate for the analysis performed, and had recoveries that met QC requirements

- Whether or not documentation of all QC sample preparation was complete and properly performed

- Whether or not spectra lines, emissions, particle energies, peak areas, and background peak areas support the identified radionuclide and its concentration

\section{A.4.6.3 Tier III}

Data quality considerations that are included in EPA data review functional guidelines as a Tier III review include the additional evaluations:

\section{Radioanalytical:}

- QC sample results (e.g., calibration source concentration, percent recovery, and RPD) verified

- Radionuclides and their concentration appropriate considering their decay schemes, half-lives, and process knowledge and history of the facility and site

- Each identified line in spectra verified against emission libraries and calibration results

- Independent identification of spectra lines, area under the peaks, and quantification of radionuclide concentration in a random number of sample results 
Tier I and II data evaluations are summarized in a memorandum for each SDG showing results and qualifiers that were changed and the reasons for these changes. A Tier III review of 50 percent of the analytical data is currently being performed by Lockheed Martin Technology Services in Las Vegas, Nevada. Changes to the data resulting from this review will be documented in IT project files and included in Table A.3-1.

\section{A.4.7 Quality Control Samples}

One field blank, one equipment rinsate blank, and one field duplicate were collected and submitted for laboratory analysis as shown in Table A.3-1. The blanks and duplicate were assigned individual sample numbers and sent to the laboratory "blind." Additional samples were selected by the laboratory to be analyzed as laboratory duplicates. The field blank was taken by placing distilled water into an appropriate sample bottle and preserved according to the requirements specified in the Industrial Sites QAPP (DOE/NV, 1996b). The equipment rinsate blank was obtained by collecting the final rinse solution (i.e., distilled water), which was poured over the decontaminated sampling equipment into the appropriate sample bottles and preserved as applicable. The results of the QC samples are discussed in the following sections.

\section{A.4.7.1 Field Quality Control Samples}

The MDC for the ${ }^{238} \mathrm{Pu}$ in the rinsate water samples varied from a low of 0.017 picocuries per liter (pCi/L) to a high of $0.27 \mathrm{pCi} / \mathrm{L}$. The ${ }^{238} \mathrm{Pu}$ concentration in water samples was not positive; the $2 \sigma$ counting error exceeded the measurement for every sample. There is no data on the concentration of plutonium in water samples taken from background locations. The derived concentration guide (DCG) for ${ }^{238} \mathrm{Pu}$ established in U.S. Department of Energy Order 5400.5 for protection of members of the public from DOE operations is 40 to $3,000 \mathrm{pCi} / \mathrm{L}$, depending on the chemical form of the plutonium (DOE, 1993). The MDCs for ${ }^{238} \mathrm{Pu}$ in water were two orders of magnitude less than the most restrictive DCG.

The MDC for ${ }^{239 / 240} \mathrm{Pu}$ in the rinsate water samples varied from a low of $0.19 \mathrm{pCi} / \mathrm{L}$ to a high of $0.29 \mathrm{pCi} / \mathrm{L}$. The DCG for ${ }^{239 / 240} \mathrm{Pu}$ in water varies from 30 to $2,000 \mathrm{pCi} / \mathrm{L}$. The MDCs for ${ }^{239 / 240} \mathrm{Pu}$ in water were at least two orders of magnitude less than the most restrictive DCG. The plutonium 
alpha spectroscopy results demonstrate that there is no plutonium contamination in the Cactus Spring rinsate water samples.

During the sampling event, one field duplicate soil sample was sent as a blind sample to the laboratory to be analyzed for isotopic plutonium. None of the samples exceeded respective MDCs; therefore, the field duplicate sample provided no information regarding the precision capabilities of the analytical laboratory for plutonium alpha spectroscopy. However, the laboratory's precision capabilities were demonstrated via four laboratory control samples.

\section{A.4.7.2 Laboratory Quality Control Samples}

Laboratory control samples (LCS) and LCS duplicates are prepared and analyzed by the contract analytical laboratory to determine the accuracy and precision of the laboratory's plutonium alpha spectroscopy analysis. The requirements for accuracy and precision are derived from EPA guidance developed for organic and inorganic analysis. The EPA has not published any guidance on the requirements for accuracy and precision in the radioanalysis of environmental remediation samples.

The accuracy requirement for LCS is established in the Industrial Site QAPP (DOE/NV, 1996b) and is defined for plutonium alpha spectroscopy as a percent recovery in the range of 80 to 120 percent. The precision requirement for an LCS duplicate is established in the Industrial Site QAPP and is defined for plutonium alpha spectroscopy as a relative percent difference of less than 25 percent. The analytical laboratory prepared two water LCS, a soil LCS, one water LCS duplicate, and a method blank and analyzed them with the CAU 485 samples. The percent recovery and relative percent difference for the water LCS for ${ }^{238} \mathrm{Pu}$ and ${ }^{239 / 240} \mathrm{Pu}$ were within requirements. The percent recovery for the ${ }^{238} \mathrm{Pu}$ in the soil LCS was 76 percent, which is just outside the accepted range. The percent recovery for the ${ }^{239 / 240} \mathrm{Pu}$ in the soil LCS was 97 percent. The relative percent difference for ${ }^{238} \mathrm{Pu}$ and ${ }^{239 / 240} \mathrm{Pu}$ in the LCS duplicate was 22 percent and 10 percent respectively. The RPD is within the requirement of less than 25 percent. None of the CAU 485 plutonium alpha spectroscopy data was rejected or assigned an analytical qualifier due to the analysis of the LCS or LCS duplicate analytical results. 
Documentation of the data qualifications resulting from the application of these guidelines is retained in IT project files as both hard copy and electronic media and will be supplied upon request.

\section{A.4.8 Field Deficiencies/Nonconformance}

During the Cactus Spring Ranch preliminary assessment investigation activities, no QA surveillances were conducted. No nonconformances or deficiencies were issued during this investigation. 
Based on the plutonium isotopic alpha spectroscopy analysis of soil samples, there is no plutonium contamination at the Cactus Spring Ranch CAU. The Tier II review of the Cactus Spring analytical data package demonstrates that the data are acceptable. All QA/QC requirements were met. The concentrations of ${ }^{238} \mathrm{Pu}$ and ${ }^{239 / 240} \mathrm{Pu}$ in all soil and water rinsate samples were less than the method minimum detectable concentrations. 


\section{A.6.0 References}

DOE, see U.S. Department of Energy.

DOE/NV, see U.S. Department of Energy, Nevada Operations Office.

EPA, see U.S. Environmental Protection Agency.

FFACO, see Federal Facility Agreement and Consent Order.

Federal Facility Agreement and Consent Order. 1996. Agreed to by the State of Nevada, the U.S. Department of Energy, and the U.S. Department of Defense.

IT, see IT Corporation.

IT Corporation. 1993, as amended. ITLV Program Procedures Manual. Las Vegas, NV.

IT Corporation. 1998. Preliminary Assessment for CAU 485: Cactus Spring Ranch Pu and DU Site, CAS No. TA-39-001-TAGR: Soil Contamination, Tonopah Test Range, Nevada. Las Vegas, NV.

McArthur, R.D., and F.L. Miller, Jr. 1989. Off-site Radiation Exposure Review Project (ORERP), Phase II Soil Program, DOE/NV/10384-23. Las Vegas, NV: Desert Research Institute.

National Academy of Sciences. 1965. Radiochemistry of Plutonium. Washington, DC.

NDEP, see State of Nevada Division of Environmental Protection.

State of Nevada Division of Environmental Protection. 1998. Letter from Paul Liebendorfer of NDEP to Runore Wycoff of DOE/NV regarding "Preliminary Assessment Report for Corrective Action Unit 485, Cactus Spring Ranch Pu and DU Site, Tonopah Test Range," 24 April. Carson City, NV.

U.S. Department of Energy. 1993. DOE Order 5400.5, Change 2, Radiation Protection of the Public and the Environment. Washington, DC.

U.S. Department of Energy, Nevada Operations Office. 1996a. Corrective Action Unit Work Plan Tonopah Test Range. Las Vegas, NV: IT Corporation.

U.S. Department of Energy, Nevada Operations Office. 1996b. Industrial Sites Quality Assurance Project Plan, Nevada Test Site, Nevada, Rev. 1. Las Vegas, NV. 
U.S. Department of Energy, Nevada Operations Office. 1997. Corrective Action Investigation Plan: Cactus Spring Waste Trenches, Rev. 2. Las Vegas, NV: IT Corporation.

U.S. Environmental Protection Agency. 1987. Data Quality Objectives for Remedial Response Activities, EPA/540/G-87-003. Washington, DC.

U.S. Environmental Protection Agency. 1994. Guidance for the Data Quality Objectives Process, EPA QA/G-4. Washington, DC. 


\section{Appendix B}

Nevada Environmental Restoration Project Document Review Sheet 


\section{NEVADA ENVIRONMENTAL RESTORATION PROJECT}

DOCUMENT REVIEW SHEET

(Page 1 of 1)

\begin{tabular}{|c|c|c|c|c|c|}
\hline \multicolumn{4}{|c|}{ 1. Document Title/Number: CADD/CR for CAU 485: Cactus Spring Ranch Pu and DU Site, TTR, Nevada } & \multicolumn{2}{|l|}{ 2. Document Date: May 1998} \\
\hline \multicolumn{4}{|c|}{ 3. Revision Number: Draft, Rev. O } & \multicolumn{2}{|c|}{ 4. Originator/Organization: IT Corporation } \\
\hline \multicolumn{4}{|c|}{ 5. Responsible DOE/NV ERP Subproject Mgr.: Sabine Curtis } & \multicolumn{2}{|c|}{ 6. Date Comments Due: June 22, 1998} \\
\hline \multicolumn{6}{|c|}{ 7. Review Criteria: Full } \\
\hline \multicolumn{4}{|c|}{ 8. Reviewer/Organization/Phone No.: Mike McKinnon } & \multicolumn{2}{|l|}{ 9. Reviewer's Signature: } \\
\hline $\begin{array}{l}\text { 10. Comment } \\
\text { Number/ } \\
\text { Location }\end{array}$ & 11. Type* & 12. Comment & \multicolumn{2}{|c|}{ 13. Comment Response } & 14. Accept \\
\hline 1 & M & $\begin{array}{l}\text { I was told that animal carcasses were buried on site at Cactus } \\
\text { Spring Ranch. If so, these burial areas should be identified in the } \\
\text { CADD/CR for future reference/remediation. There was no reference } \\
\text { to these burial areas in either the Preliminary Assessment Report or } \\
\text { the CADD/CR. If animal carcasses were not buried at this location, } \\
\text { this fact should also be addressed in the CADD/CR. }\end{array}$ & \multicolumn{2}{|c|}{$\begin{array}{l}\text { The following text has been added to the CAU description in } \\
\text { Section 2.0: "These animals were sacrificed after the tests. } \\
\text { The location of the animals' carcasses has not been } \\
\text { determined. Process knowledge does not indicate that the } \\
\text { carcasses would be found within CAU 485; therefore, } \\
\text { CAU } 485 \text { is not concerned with these carcasses. If process } \\
\text { knowledge is identified that requires further environmental } \\
\text { investigation at Cactus Spring Ranch, the site may be } \\
\text { assigned new CAU and CAS designations." }\end{array}$} & \\
\hline
\end{tabular}

${ }^{*}$ Comment Types: $M$ = Mandatory, $S=$ Suggested

Return Document Review Sheets to DOE/NV Environmental Restoration Division, Attn: QAC, M/S 505. 


\section{Distribution}

Paul J. Liebendorfer

State of Nevada

Bureau of Federal Facilities

Division of Environmental Protection

333 W. Nye Lane, Room 138

Carson City, NV 89706-0851

Supervisor

State of Nevada

Bureau of Federal Facilities

Division of Environmental Protection

555 E. Washington, Suite 4300

Las Vegas, NV 89101

Sabrina Lawrence

Environmental Restoration Division

DOE/Nevada Operations Office

P.O. Box 98518, M/S 505

Las Vegas, NV 89193-8518

Janet Appenzeller-Wing

Environmental Restoration Division

DOE/Nevada Operations Office

P.O. Box 98518, M/S 505

Las Vegas, NV 89193-8518

Sabine Curtis

Environmental Restoration Division

DOE/Nevada Operations Office

P.O. Box 98518, M/S 505

Las Vegas, NV 89193-8518

Col. M. Fukey

$99 \mathrm{ABW} / \mathrm{EM}$

4349 Duffer Drive, Suite 1601

Nellis AFB, NV 89191-7007

Technical Information Resource Center

DOE/Nevada Operations Office

P.O. Box 98518, M/S 505

Las Vegas, NV 89193-8518
2 (Controlled)

1 (Controlled)

1 (Controlled)

1 (Uncontrolled)

1 (Uncontrolled)

3 (Controlled)

1 (Uncontrolled) 
U.S. Department of Energy

2 (Uncontrolled)

Office of Scientific and Technical Information

P.O. Box 62

Oak Ridge, TN 37831

DOE Public Reading Room

1 (Controlled)

P.O. Box 98521, M/S NLV040

1 (Uncontrolled)

Las Vegas, NV 89193-8521

Jeffrey L. Smith

1 (Uncontrolled)

Bechtel Nevada

P.O. Box 98521, M/S NTS306

Las Vegas, NV 89193-8521

Steve Nacht

1 (Uncontrolled)

Bechtel Nevada

P.O. Box 98521, M/S NTS306

Las Vegas, NV 89193-8521

Dustin Wilson

1 (Uncontrolled)

SAIC

P.O. Box 93838

Las Vegas, NV 89193

Cheryl Rodriguez

1 (Uncontrolled)

HSI GeoTrans

P.O. Box 93838

Las Vegas, NV 89193

IT Corporation Central Files

1 (Uncontrolled)

IT Corporation

P.O. Box 93838

Las Vegas, NV 89193

Rosa Silver

1 (Controlled)

IT Corporation

1 (Uncontrolled)

P.O. Box 93838

Las Vegas, NV 89193

Mary Todd

1 (Uncontrolled)

SAIC

P.O. Box 93838

Las Vegas, NV 89193 